\title{
Beta amyloid and hyperphosphorylated tau deposits in the pancreas in type 2 diabetes
}

\author{
Judith Miklossy ${ }^{\mathrm{a}, *}$, Hong Qing ${ }^{\mathrm{a}}$, Aleksandra Radenovic ${ }^{\mathrm{b}}$, Andras Kis ${ }^{\mathrm{b}}$, Bertrand Vileno ${ }^{\mathrm{b}}$, \\ Forró Làszló ${ }^{\mathrm{b}}$, Lisa Miller ${ }^{\mathrm{c}}$, Ralph N. Martins ${ }^{\mathrm{d}}$, Gerard Waeber ${ }^{\mathrm{e}}$, Vincent Mooser ${ }^{\mathrm{f}}$, \\ Fred Bosman $^{\mathrm{g}}$, Kamel Khalili ${ }^{\mathrm{h}}$, Nune Darbinian ${ }^{\mathrm{h}, \mathrm{i}}$, Patrick L. McGeer ${ }^{\mathrm{a}}$ \\ ${ }^{a}$ Kinsmen Laboratory of Neurological Research, University of British Columbia, 2255 Wesbrook Mall, 3 N6 Vancouver, B.C., V6T1Z3 Canada \\ b Institute of Physics of Complex Matter, Swiss Federal Institute of Technology, CH-15 Lausanne, Switzerland \\ ${ }^{\mathrm{c}}$ Brookhaven National Laboratory, National Synchrotron Light Source, Upton, NY, USA \\ d Sir James McCusker Alzheimer's Disease Research Unit, School of Psychiatry and Clinical Neurosciences, \\ University of Western Australia, Hollywood Private Hospital, Perth, Western Australia, Australia \\ e Department of Internal Medicine, CHUV-University Hospital, Lausanne, Switzerland \\ ${ }^{\mathrm{f}}$ Division of Genetics, GlaxoSmithKline, King of Prussia, PA, USA \\ $\mathrm{g}$ University Institute of Pathology, CHUV, Lausanne, Switzerland \\ h Department of Neuroscience, Institute of Neurovirology, Temple University, Philadelphia, PA, USA \\ ${ }^{i}$ Centre of Excellence for Alzheimer's Disease Research and Care, Edith Cowan University, Western Australia, Australia
}

Received 26 April 2008; received in revised form 23 August 2008; accepted 25 August 2008

Available online 23 October 2008

\begin{abstract}
Strong epidemiologic evidence suggests an association between Alzheimer disease (AD) and type 2 diabetes. To determine if amyloid beta $(\mathrm{A} \beta)$ and hyperphosphorylated tau occurs in type 2 diabetes, pancreas tissues from 21 autopsy cases (10 type 2 diabetes and 11 controls) were analyzed. APP and tau mRNAs were identified in human pancreas and in cultured insulinoma beta cells (INS-1) by RT-PCR. Prominent APP and tau bands were detected by Western blotting in pancreatic extracts. Aggregated A $\beta$, hyperphosphorylated tau, ubiquitin, apolipoprotein E, apolipoprotein(a), IB1/JIP-1 and JNK1 were detected in Langerhans islets in type 2 diabetic patients. A $\beta$ was co-localized with amylin in islet amyloid deposits. In situ beta sheet formation of islet amyloid deposits was shown by infrared microspectroscopy (SIRMS). LPS increased APP in non-neuronal cells as well. We conclude that A $\beta$ deposits and hyperphosphorylated tau are also associated with type 2 diabetes, highlighting common pathogenetic features in neurodegenerative disorders, including AD and type 2 diabetes and suggesting that $\mathrm{A} \beta$ deposits and hyperphosphorylated tau may also occur in other organs than the brain.
\end{abstract}

(C) 2008 Elsevier Inc. All rights reserved.

Keywords: Alzheimer's disease; Amylin; Beta amyloid; Apolipoprotein-E; Apolipoprotein-a; APP; LPS; Type 2 diabetes; IB1/JIP-1; JNK-1; Tau; Ubiquitin

\section{Introduction}

Strong epidemiologic evidence supports an association between Alzheimer's disease (AD) and type 2 diabetes (Janson et al., 2004; Ott et al., 1999; Ristow, 2004; Voisin et al., 2003). AD is a neurodegenerative disorder characterized by a slowly progressive dementia and brain atrophy. The degenerative process affects primarily the neocortical

\footnotetext{
* Corresponding author. Tel.: +1 41792074442.

E-mail address: judithmiklossy @bluewin.ch (J. Miklossy).
}

and limbic cortices, where there is an accumulation of senile plaques mainly consisting of beta amyloid protein $(A \beta)$ deposits and neurofibrillary tangles (NFTs), mainly consisting of hyperphosphorylated tau.

Type 2 diabetes formerly termed noninsulin-dependent diabetes mellitus (NIDDM), or adult-onset diabetes, is characterized by a slowly progressive degeneration of islet $\beta$-cells, resulting in a fall of insulin secretion and decreased insulin action on peripheral tissues. Type 2 is the most common form of diabetes, comprising 90-95\% of all diabetic cases (O'Brien et al., 2003). Its etiology is multifactorial and 
its pathogenesis has been not completely resolved. The extent of amyloid deposition is associated with the severity of beta cell loss and the impairment in insulin secretion and glucose metabolism, suggesting a causative role for islet amyloid in the degenerative process in type 2 diabetes (Hull et al., 2004).

Deposition of amyloid material is a major pathological feature of both $\mathrm{AD}$ and type 2 diabetes. In $\mathrm{AD}$, the amyloid deposits consist mainly of aggregates of beta amyloid protein $(A \beta)$. A $\beta$ includes peptides of 40 and $42-43$ amino acid length which accumulate following proteolytic cleavage of amyloid beta precursor protein (APP). The exact physiological function of $A \beta$ is not known.

Islet amyloid deposits are present in more than $95 \%$ of type 2 diabetic patients (Lopes et al., 2004). The extent of islet amyloid deposits correlates with the clinical severity of the disease (Cooper et al., 1987a,b). The deposits are mainly comprised of amylin, also known as islet amyloid polypeptide (IAPP) (Cooper et al., 1987a,b; Westermark et al., 1987). This 37 amino acid peptide is derived by proteolytic cleavage of the 89-amino acid islet amyloid precursor protein (Cooper et al., 1987a,b; Sanke et al., 1988). It has been suggested that amylin is a hormone, related to the calcitonin/calcitonin gene-related peptide family, and is involved in homeostatic maintenance (Cooper et al., 1988). Along with insulin, amylin is produced by $\beta$-cells in the Langerhans islets of the pancreas. Because of the accumulating evidence that a link exists between AD and type 2 diabetes, we investigated whether $A \beta$ deposits and phosphorylated tau aggregates may also develop in the pancreas in type 2 diabetes. Analysis of the in situ infrared microspectra of islet amyloid deposits was also performed to detect the typical secondary protein structure using synchrotron infrared microspectroscopy (SIMRS).

The bacterial lipopolysaccharide (LPS), a powerful inflammatory stimulator, induces increased APP levels and increased $A \beta \quad 1-42$ in vitro in neuronal cell cultures and in vivo in the central nervous system. Insulin decreases APP in neurons and therefore has a protective effect. Whether LPS and insulin may also influence APP levels in non-neuronal cells is not known. We used Western blot analysis to test whether LPS and recombinant human insulin may also influence APP levels in non-neuronal TE671 and U87MG cells compared to PC12 cells.

\section{Methods}

\subsection{Autopsy cases}

Pancreas tissue of 21 autopsy cases was analyzed (Table 2). Ten of the 21 cases had clinically and pathologically confirmed type 2 diabetes (average age: 75.69; range 73-98) with one having a concurrent pancreatic cancer. All diabetic patients had long standing noninsulin-dependent diabetes (NIDDM) except one (case 13 of Table 2). This 78 year old patient with two decades history of severe type 2 diabetes has had become insulin-dependent several years before death (case 13, Table 2). The other eleven patients with no clinical or pathological record of type 2 diabetes were used as controls

Table 1

Antibodies utilized in the current study.

\begin{tabular}{|c|c|c|c|c|}
\hline Antigen & Antibody (ref.) & Source & Type & Dilution \\
\hline 6F/3D, M0872 & $\mathrm{A} \beta \mathrm{8}-17$ & DakoCytomation & Mouse IgG & $1: 1000$ \\
\hline $4 \mathrm{G} 8$ & $A \beta 17-24$ & Sigma-Aldrich & Mouse IgG & $1: 100$ \\
\hline 2F9AF & $A \beta 17-28$ & & Mouse IgG & $1: 400$ \\
\hline $\mathrm{A} \beta \mathrm{1}-40 \mathrm{C}$ terminus & KHB3481 & QCB, Hopkinton, MA & Rabbit IgG & $1: 500$ \\
\hline $\mathrm{A} \beta \mathrm{1}-42 \mathrm{C}$ terminus & $88-344$ & QCB, Hopkinton, MA & Rabbit IgG & $1: 500$ \\
\hline $21 \mathrm{~F} 12$ & $A \beta 1-42$ & Johnson-Wood et al. (1997) & Mouse IgG & $1: 500$ \\
\hline $\mathrm{A} \beta$ & $\mathrm{A} \beta 1-40$ & Dr. H. Mori & Rabbit IgG & $1: 200$ \\
\hline $\mathrm{A} \beta$ & $\mathrm{A} \beta 1-42$ & Dr. H. Mori & Rabbit IgG & $1: 200$ \\
\hline $\mathrm{A} \beta \mathrm{PP}, 22 \mathrm{C} 11$ & MAB348 & Chemicon, Temecula, CA & Mouse IgG & $1: 500$ \\
\hline Amylin(1) & IAPP $1-37$ & Gift of Dr. A. Clark & Rabbit IgG & $1: 400$ \\
\hline Amylin(2) & IAPP $1-37$ & Gift of Dr. A. Clark & Rabbit IgG & $1: 100$ \\
\hline Amylin a.a. 29-37 & GTX 74673 & GeneTex, Inc. & Mouse IgG & 1: 200 \\
\hline Tau & $\mathrm{A} 0024$ & DakoCytomation & Rabbit IgG & $1: 200$ \\
\hline Tau & T-6402 & Sigma & Rabbit IgG & $1: 1000$ \\
\hline Tau & $\mathrm{T}-5530$ & Sigma-Aldrich & Mouse IgG & $1: 200$ \\
\hline Tau, clone tau 2 & MAB375 & Chemicon & Mouse IgG & $1: 500$ \\
\hline Anti-phospho-tau & pSer409 & Sigma-Aldrich & Mouse IgG & $1: 100$ \\
\hline AT-8 & BR-03 & Endotellin & Mouse IgG & $1: 100$ \\
\hline Tau & C3 & L. I. Binder (Northwestern University, Chicago) & Mouse IgG & $1: 5000$ \\
\hline Ubiquitin & Z 0458 & DakoCytomation & Rabbit IgG & $1: 200$ \\
\hline Apo-E & 0650-1904 & Biogenesis & Goat IgG & $1: 100$ \\
\hline Apo-E & 1062 & Chemicon & Mouse IgG & $1: 100$ \\
\hline Apolipoprotein-a & Marcovina et al. (1995) & & Mouse IgG & $1: 100$ \\
\hline IB-1 & Pellet et al. (2000) & & Rabbit IgG & $1: 100$ \\
\hline JNK-1 & $56 \mathrm{~GB}$ & Cell signaling & Rabbit IgG & $1: 100$ \\
\hline Grb-2 & G16720-050 & BD Transd. Lab & Mouse IgG & $1: 1000$ \\
\hline
\end{tabular}


Table 2

Illustration of the results of the immunohistochemical analysis.

\begin{tabular}{|c|c|c|c|c|c|c|c|c|c|c|c|}
\hline Case & $\mathrm{Dg}$ & Age & Sex & A & $\mathrm{A} \beta$ & (p)Tau & Ubi & Apo-E & Apo(a) & IB1 & JNK-1 \\
\hline 1 & $\mathrm{~T} 2 \mathrm{D}$ & 76 & M & + & + & + & + & + & + & + & + \\
\hline 2 & $\mathrm{~T} 2 \mathrm{D}$ & 70 & M & + & + & + & + & + & + & + & + \\
\hline 3 & $\mathrm{~T} 2 \mathrm{D}$ & 98 & $\mathrm{~F}$ & + & + & + & + & + & + & - & - \\
\hline 4 & $\mathrm{~T} 2 \mathrm{D}$ & 69 & $\mathrm{~F}$ & + & + & + & + & + & + & + & + \\
\hline 5 & $\mathrm{~T} 2 \mathrm{D}$ & 79 & M & + & + & + & + & + & + & + & + \\
\hline 6 & $\mathrm{~T} 2 \mathrm{D}$ & 77 & M & + & + & + & + & + & + & + & + \\
\hline 7 & $\mathrm{~T} 2 \mathrm{D}$ & 77 & $\mathrm{~F}$ & + & + & + & + & + & + & + & + \\
\hline 8 & $\mathrm{~T} 2 \mathrm{D}$ & 73 & M & + & + & + & + & + & + & + & + \\
\hline 9 & $\mathrm{~T} 2 \mathrm{D}$ & 73 & $\mathrm{~F}$ & + & + & + & + & + & + & + & + \\
\hline 10 & $\mathrm{~T} 2 \mathrm{D}$ & 66 & $\mathrm{~F}$ & + & + & + & + & + & + & + & + \\
\hline 11 & $\mathrm{~T} 2 \mathrm{D}$ & 75 & M & + & + & + & + & + & + & + & + \\
\hline 12 & $\mathrm{~T} 2 \mathrm{D}$ & 73 & $\mathrm{~F}$ & + & + & + & + & + & + & + & + \\
\hline 13 & $\mathrm{~T} 2 \mathrm{D}$ & 78 & M & + & + & + & + & - & - & - & - \\
\hline 14 & CTR & 78 & $\mathrm{~F}$ & 0 & 0 & 0 & 0 & - & - & - & - \\
\hline 15 & CTR & 76 & $\mathrm{~F}$ & 0 & 0 & 0 & 0 & 0 & 0 & 0 & 0 \\
\hline 16 & CTR & 69 & $\mathrm{~F}$ & 0 & 0 & 0 & 0 & 0 & 0 & 0 & 0 \\
\hline 17 & CTR & 60 & M & 0 & 0 & 0 & 0 & 0 & 0 & - & - \\
\hline 18 & CTR & 70 & M & 0 & 0 & 0 & 0 & 0 & 0 & 0 & 0 \\
\hline 19 & CTR & 75 & $\mathrm{~F}$ & 0 & 0 & 0 & 0 & 0 & 0 & 0 & 0 \\
\hline 20 & CTR & 73 & M & + & + & + & + & + & + & + & + \\
\hline 21 & CTR & 76 & $\mathrm{~F}$ & + & + & + & + & + & + & + & + \\
\hline 22 & CTR & 56 & M & 0 & 0 & 0 & 0 & 0 & 0 & 0 & 0 \\
\hline 23 & CTR & 54 & $\mathrm{~F}$ & 0 & 0 & 0 & 0 & 0 & 0 & 0 & 0 \\
\hline 24 & CTR & 67 & M & 0 & 0 & 0 & 0 & 0 & 0 & 0 & 0 \\
\hline
\end{tabular}

Abbreviations: Dg: diagnosis; A: islet amyloid polypeptide as verified by thioflavin S and anti-amylin immunostaining; A 3 : beta amyloid; (p)Tau: hyperphosphorylated tau; Ubi: ubiquitin; Apo-E: apolipoprotein-E; Apo(a): apolipoprotein(a); IB1: Islet-brain-1 or C-Jun N-terminal kinase interacting protein-1 (IB1/JIP-1); JNK-1: c-Jun NH2-terminal kinase-1; T2D: type 2 diabetes; CTR: control; +: positive immunoreaction; 0: no immunoreaction; -: the analysis was not performed.

(average age: 68.54; range 54-78). In these cases with normal sugar level, specific tests for diabetes were not performed and nothing in favor of diabetes was clinically recorded. The time lapse between death and autopsy varied between 6 and $24 \mathrm{~h}$ in type 2 diabetic cases and between 8 and $30 \mathrm{~h}$ in control autopsy cases. The use of post mortem delays between 6 and $30 \mathrm{~h}$ has guaranteed a consistent and comparable quality of the material used for the histological and molecular analyses, including the mRNA analysis (Yasojima et al., 2001).

In each case, a sample of about $2 \mathrm{~cm} \times 1 \mathrm{~cm} \times 0.5 \mathrm{~cm}$ was dissected from the pancreas and frozen in liquid $\mathrm{N}_{2}$ or at $-80^{\circ} \mathrm{C}$ until processing. These samples were used for molecular biological and immunohistochemical analyses. A further sample was taken for embedding in paraffin and was used for histochemical and immunohistochemical investigations.

\subsection{Cell lines}

Rat insulinoma INS-1 cell line (Asfari et al., 1992) was cultured in RPMI 1640 medium containing $11.1 \mathrm{mmol} / \mathrm{l}$ glucose and supplemented with $10 \%$ fetal calf serum, $2 \mathrm{mmol} / \mathrm{l} \mathrm{L}$-glutamine, $1 \mathrm{mmol} / 1$ sodium pyruvate, $50 \mu \mathrm{mol} / \mathrm{l}$ $\beta$-mercaptoethanol, penicillin $(50 \mathrm{U} / \mathrm{ml})$, and streptomycin (50 U/ml) (Martin et al., 2003).

Cells of the human neuroblastoma SH-SY5Y cell line (ATCC CRL-2266; a gift from Dr. R. Ross, Fordham University, NY) were grown in Dulbecco modified Eagle medium-nutrient mixture F12 Ham (DMEM-F12) supple- mented with $10 \%$ fetal bovine serum (FBS; GIBCO BRL, Life Technologies, Burlington, ON, Canada) containing $50 \mu \mathrm{g} / \mathrm{ml}$ gentamicin (Miklossy et al., 2006). RNA and protein extracts of these cells, which are known to contain APP and tau, were used as positive controls for the detection of APP and tau in pancreas tissues and in INS-1 beta cells.

N2a neuroblastoma cells were obtained from the American Type Culture Collection (ATCC) and cultured in the same medium as SH-SY5Y cells. N2a cells contain APP and tau and were used as an additional positive control for the detection of APP and tau in pancreas tissues and in INS-1 beta cells. N2a cells over-expressing APP were also used as positive control for Western blot analysis of APP. Transient transfection was carried out using the APP695swe plasmid (kindly provide by Dr. Weihong Song, Brain Research Center, University of British Columbia, Canada) using LipofectAMINE2000 (Invitrogen) according to the manufacturer's instructions. For transient transfection, cells were grown to about $90 \%$ confluence and transfected with the plasmids. Cells were harvested $48 \mathrm{~h}$ following transfection.

Rat pheochromocytoma PC12 cells (ATTC, CRL-1721) showing neuronal characteristics by expressing catecholamines, dopamine and norepinephrine $\left(0.3 \times 10^{6}\right)$, were plated into collagen coated Petri dishes $(100 \mathrm{~mm})$ and cultured in $10 \mathrm{ml}$ of F12 Nutrient Mixture (HAM, 11765-054, Life Technologies, Gibco/BRL, Frederick, Maryland) supplemented with $10 \%$ horse serum, 5\% FBS, $1 \%$ penicillin/ streptomycin and $870 \mathrm{mg} \mathrm{NaHCO} 3$ per $500 \mathrm{ml}$ medium. 
Human TE 671 cells (subline No. 2; ATCC, HTB-139) showing characteristics of striated muscle expressing myoglobin and desmin $\left(0.3 \times 10^{6}\right)$ and human U87MG cells showing characteristics of glial cells were plated in $100 \mathrm{~mm}$ Petri dishes and were cultured in DMEM containing 10\% fetal bovine serum (FBS) and $1 \%$ penicillin/streptomycin in a humidified, $6 \% \mathrm{CO}_{2}$ incubator at $37^{\circ} \mathrm{C}$.

\subsection{RNA isolation and cDNA synthesis by reverse transcription}

RNA was extracted from $100 \mathrm{mg}$ fresh pancreas tissue samples of 9 patients (6 with type 2 diabetes and 3 controls) and from harvested INS-1 islet beta cells and SH-SY5Y cells using TRI-Reagent (Invitrogen, Life Technologies, Burlington, ON, Canada) following the instructions of the manufacturer. Samples $(100 \mathrm{mg}$ ) of the frontal cortex in four patients ( 3 with type 2 diabetes and 1 control) were also analyzed and were used as positive controls. Two $\mu \mathrm{g}$ of RNA extract was treated with $10 \mathrm{U}$ of DNase I (Invitrogen Life Technologies, Burlington, ON, Canada) for $60 \mathrm{~min}$ at $37^{\circ} \mathrm{C}$ in $25 \mu \mathrm{l}$ of $1 \times$ reverse transcription buffer $(50 \mathrm{mM}$ Tris- $\mathrm{HCl}, 75 \mathrm{mM} \mathrm{KCl}, 3 \mathrm{mM} \mathrm{MgCl}$ ) containing $40 \mathrm{U}$ of RNase inhibitor (Amersham Biosciences, Baie d'Urfé, PQ, Canada) and $1 \mathrm{mM}$ dithiothreitol (DTT). This was followed by incubation at $85^{\circ} \mathrm{C}$ for $5 \mathrm{~min}$ to inactivate the enzyme. Reverse transcription was performed at $42{ }^{\circ} \mathrm{C}$ for $90 \mathrm{~min}$ in $50 \mu \mathrm{l}$ of the following mixture: $1 \times$ reverse transcription buffer containing $2 \mu \mathrm{g}$ of RNA, $5 \mathrm{mM}$ DTT, $0.2 \mu \mathrm{g}$ random hexamer primers (Amersham Biosciences), $1 \mathrm{mM}$ deoxynucleotides (Invitrogen Life Technologies), $40 \mathrm{U}$ of RNase inhibitor, and $400 \mathrm{U}$ of SuperScript II reverse transcriptase (Invitrogen Life Technologies). At the end of the incubation period, the enzyme was inactivated by heating at $65^{\circ} \mathrm{C}$ for $10 \mathrm{~min}$.

One microliter of the transcription reaction solution was amplified by polymerase chain reaction (PCR) for APP and tau. The PCR reaction was carried out in a $25 \mu \mathrm{l}$ mixture containing $1 \times$ GeneAmp PCR buffer II (Applied Biosystems, Streetsville, ON, Canada), 1.25 U of AmpliTaq Gold DNA polymerase (Applied Biosystems), $2 \mathrm{mM} \mathrm{MgCl}_{2}$ (Applied Biosystems), $200 \mu \mathrm{M}$ dNTPs (Invitrogen Life Technologies, Burlington, ON, Canada), and $0.5 \mu \mathrm{M}$ of each primer. The amplification program consisted of an initial denaturation step at $94^{\circ} \mathrm{C}$, which was extended to $9 \mathrm{~min}$ in order to activate AmpliTaq Gold enzyme. This was followed by an annealing step at $55^{\circ} \mathrm{C}$ for $1 \mathrm{~min}$ and an initial synthesis step at $72^{\circ} \mathrm{C}$ for $3 \mathrm{~min}$. The remaining cycles were $1 \mathrm{~min}$ at $94^{\circ} \mathrm{C}, 1 \mathrm{~min}$ at $55^{\circ} \mathrm{C}$ and $1 \mathrm{~min}$ at $72{ }^{\circ} \mathrm{C}$. The number of cycles performed was 25-30.

The following primers were used for the amplification of APP and tau. APP gene-specific forward 5'-CGGAATTCCCTTGGTGTTCTTTGCAGAAG-3' and reverse 5'-CGGAATTCCGTTCTGCATCTGCTCAAAG-3' primers were used to amplify a $248 \mathrm{bp}$ fragment of the APP coding region. The TAU gene-specific forward primer 5'-GCCAACGCCA-
CCAGGATTC-3' and reverse primer 5'-AGTAGCCGTCTTCCGCC- $3^{\prime}$ were used to amplify a 221 bp fragment of the tau coding region. Glyceraldehyde 3-phosphate dehydrogenase $(G A P D H)$, a key enzyme involved in glycolysis, which is constitutively expressed at high levels in almost all tissues was amplified in the same conditions and was used as a loading control. GAPDH gene-specific forward primer 5'-CATGCCGCCTGGAGAACCTGCCA- $3^{\prime}$ and reverse primer $5^{\prime}$-TGGGCTGGGTGGTCCAGGGGTTTC- $3^{\prime}$ were used to amplify a $251 \mathrm{bp}$ fragment of $G A P D H$. After amplification, PCR products were separated on $2 \%$ agarose gel and visualized by incubation for $10 \mathrm{~min}$ in a solution containing $10 \mathrm{ng} / \mathrm{ml}$ of ethidium bromide. Polaroid photographs of the gels were taken by Kodak Image Station 1000 software (PerkinElmer, Norwalk, CT, USA).

\subsection{Immunoblotting}

Frozen pancreas tissue samples of six patients (4 patients with type 2 diabetes and two controls) and harvested N2a cells were homogenized in 5 volumes of RIPA-Doc lysis buffer containing $50 \mathrm{mM}$ Tris- $\mathrm{HCl}$ (pH 7.5), $150 \mathrm{mM} \mathrm{NaCl}, 1 \%$ sodium deoxycholate, $1 \%$ Triton X-100, $0.1 \%$ sodium dodecyl sulfate (SDS), and protease inhibitor cocktail (Complete, 1697 498, Roche Molecular Biochemicals, Indianapolis, IN). The homogenates were centrifuged at $100,000 \times g$ for $1 \mathrm{~h}$ at $4{ }^{\circ} \mathrm{C}$. The supernatant was taken and the protein concentration was determined using $\mathrm{DC}^{\mathrm{TM}}$ Protein Assay (Bio-Rad Laboratories Inc., CA). Samples containing $100 \mu \mathrm{g}$ protein were separated by $7.5 \%$ SDS-PAGE under reducing conditions and the proteins in the gel were electrotransferred onto a polyvinylidene fluoride (PVDF) membrane (Millipore Co., Bedford, MA). After blocking with 5\% (w/v) skim milk in TBS containing $0.1 \%$ Tween 20 , the membranes were incubated with the primary antibodies overnight at $4{ }^{\circ} \mathrm{C}$. To detect APP a monoclonal anti-APP antibody, clone 22C11 was used (MAB348, Chemicon, Temecula, CA) which recognizes an $\mathrm{N}$ terminal common epitope (a.a. 66-81) in the three major isoforms of APP. For the detection of tau, a monoclonal antibody clone tau 2 (MAB375, Chemicon) was used which recognizes both non-phosphorylated and phosphorylated tau. Following incubation of the membranes with the appropriate horseradish peroxidase (HRP)-conjugated anti-mouse (Cell Signaling Technology, Danvers, MA, USA, dilution 1:1000) or anti-rabbit antibody (Cell Signaling Technology, Danvers, MA, USA, dilution 1:1000) for $1 \mathrm{~h}$ at room temperature, immunoreactivity was visualized by chemiluminescence using ECL Western blotting system (Amersham Pharmacia Biotech, Uppsala, Sweden) and recorded on Hyperfilm ECL.

\subsection{Histochemical and immunohistochemical analysis}

Frozen $(10 \mu \mathrm{m})$ and paraffin embedded $(5 \mu \mathrm{m})$ serial sections were subsequently cut and mounted directly on glass slides. The frozen sections were post fixed overnight with $4 \%$ paraformaldehyde prior to immunohistochemical analysis. 
Paraffin and 4\% paraformaldehyde fixed sections (mounted or floating) of pancreas were stained with hematoxylin and eosin (H\&E) and with Thioflavin S and congo Red to detect amyloid deposits. For immunohistochemical analysis, antibody type, specificity and source are given in Table 1 . To detect islet amylin deposits, two rabbit polyclonal antibodies and one monoclonal antibody (clone R10/11, GeneTex, Inc.) to human amylin were used. To detect $A \beta$, paraffin sections and frozen sections post fixed in $4 \%$ paraformaldehyde were immunostained with 8 different anti-A $\beta$ antibodies. These recognized several epitopes of the peptide, including $A \beta$ 8-17 (6F/3D), A $\beta 17-24$ (4G8), A $\beta 17-28$ (2F9AF), A $\beta 40$ (QCB1-40) and $\mathrm{A} \beta 42$ (QCB1-42, 21F12). Two polyclonal antibodies, $A \beta 40$ and $A \beta 42$, which recognize the $C$-terminus of $A \beta 40$ and $A \beta 42$ respectively, were also utilized (generous gifts of Dr. H. Mori). For detection of $A \beta$, the sections were pre-treated with $80 \%$ formic acid for 20 min before immunostaining. To detect tau, the sections were immunostained with three monoclonal antibodies (Sigma T-5530, Chemicon Tau-2, and AT8 Innogenetics) and two polyclonal antibodies (T-6402, Sigma and A0024, DakoCytomation). The monoclonal tau-2 antibody and the two anti-tau polyclonal antibodies bind both, phosphorylated or non-phosphorylated forms of tau. These antibodies do not show cross-reactivity with other microtubule associated proteins. The antibody AT8 recognizes tau phosphorylated at residues Ser-202/Thr-205. The anti-phospho-tau Ser409 (Sigma-Aldrich) antibody recognizes tau at phosphorylated Ser 409. These antibodies do not cross-react with non-phosphorylated tau.

Pancreas sections were also immunostained with a polyclonal anti-ubiquitin antibody (DAKO, Z 0458) and a monoclonal anti-apolipoprotein-E antibody (MAB1062, Chemicon). Not only the apoE epsilon 4 allele, but lipoprotein-a (apo(a) is also a risk factor for late onset $\mathrm{AD}$ (Mooser et al., 2000). In order to analyze whether apo(a) may be present in association with islet amyloid deposits in type 2 diabetes, immunostaining with a mouse monoclonal anti-apo(a) antibody (Marcovina et al., 1995) was performed.

Islet-brain-1 or C-Jun N-terminal kinase interacting protein-1 (IB1/JIP-1) and c-Jun NH2-terminal kinase (JNK), were both found to be co-localized with phosphorylated tau in neurofibrillary tangles in AD (Helbecque et al., 2003). In order to analyze whether they may also be associated with degenerating lesions of the pancreas in type 2 diabetes, a rabbit affinity purified anti-IB1/JIP1 polyclonal antibody (Pellet et al., 2000) and a rabbit monoclonal anti-JNK-1 antibody (Cell signaling, 56G8) were employed.

For antibody detection, the avidin-biotin-peroxidase technique was utilized as previously described in detail (Miklossy et al., 2006). Control sections, in which the primary antibody was replaced by normal serum, were always immunostained in parallel.

A double immunofluorescence technique to detect overlapping co-expression of $A \beta$ and amylin was also carried out on pancreas sections of patients with type 2 diabetes. The sections were incubated with a mixture of rabbit anti-human
$\mathrm{A} \beta$ (A $\beta-40$ or $\mathrm{A} \beta-42$, dilution 1:100, kind gift of Dr. Mori) and a mouse monoclonal antibody to amylin (GTX74673, GeneTex, Inc., dilution 1:100) overnight at room temperature. The sections were next incubated for $1 \mathrm{~h}$ at room temperature with FITC-conjugated swine anti-rabbit antibody (DAKO; F0205, 1:30) to detect the green fluorescence of $\mathrm{A} \beta$. After washing $3 \times 5 \mathrm{~min}$ with $\mathrm{PBS}$, the sections were incubated with a TRITC-tagged rabbit anti-mouse antibody (1:100, DAKO, R0270, 1:30) to yield a red fluorescence for amylin. The sections were then mounted with FluoromountG (Southern Biotechnology Associates Inc., Birmingham, $\mathrm{AL}$ ) and examined with a Carl Zeiss Axi-overt-200 fluorescence microscope. The capture of the green amylin fluorescence, and the red fluorescence of $\mathrm{A} \beta$ as well as the merged images were performed using the Northern Elite program. Control sections with the omission of the primary antibodies were also prepared for the double immunofluorescence analyses.

A combination of immunostaining with antibodies to the various pathological proteins with Thioflavin $\mathrm{S}$ staining was also used to analyze their localization related to islet amyloid deposits. These doubly stained sections were analyzed with the same Carl Zeiss Axi-overt-200 fluorescence microscope, with and without fluorescent filters, enabling us to observe the localization of pathological proteins in bright field and areas of islet amyloid deposits by their green fluorescence.

\subsection{Synchrotron infrared microspectroscopy (SIRMS)}

The in situ infrared microspectroscopic analysis of islet amyloid deposits was performed using a Spectra Tech Continu $\mu \mathrm{m}$ infrared microscope coupled to a Nicolet Magna 860 FTIR where the conventional infrared source was replaced by a synchrotron light from Beamline U10B (National Synchrotron Light Source, Brookhaven National Laboratory) equipped with a fluorescence microscope. Unfixed $8 \mu \mathrm{m}$ thick frozen sections of the pancreas from three patients with type 2 diabetes were placed on infrared-transparent $\mathrm{BaF}_{2}$ slides and stained with Thioflavin $\mathrm{S}$. The in situ infrared microspectra of Thioflavin S positive islet amyloid deposits showing green fluorescence was compared with that obtained by analyzing unaffected areas of the pancreas without amyloid deposits. Infrared microspectra were collected in transmission mode, 128 scans per point, $4 \mathrm{~cm}^{-1}$ resolution using Atl $\mu$ s software (Thermo Electron). The final data format was absorbance, where the background was collected open beam. Protein secondary structure was determined by Amide I infrared absorption band $\left(1600-1700 \mathrm{~cm}^{-1}\right)$ analysis. The frequency of Amide I band is sensitive to protein secondary structure, where $\beta$ sheet conformation absorbs near $1630 \mathrm{~cm}^{-1}$.

\subsection{Exposure of cells to LPS and insulin}

TE671, U87MG or PC12 cells at 70\% confluence were exposed to $500 \mathrm{ng} / \mathrm{ml}$ LPS or to $100 \mathrm{ng} / \mathrm{ml}$ human recombi- 
nant insulin (Roche, 1376497$)$. For immunoblotting whole cell extracts were prepared following $0 \mathrm{~h}, 30 \mathrm{~min}, 6,24$ and $48 \mathrm{~h}$ of LPS and insulin exposures. For insulin exposure an additional extract at $3 \mathrm{~h}$ exposure was also analyzed. Following these various exposure times the cells were harvested by centrifugation and the Western blot detection of APP and tau was performed as described above.

\section{Results}

\subsection{RNA isolation and cDNA synthesis by reverse transcription}

Fig. 1 shows the expression of APP and tau mRNAs by RT-PCR in human pancreas tissues of five patients (Fig. 1A). In the four additional cases where fresh brain tissue was also available for analysis the APP and tau mRNAs bands

(A)
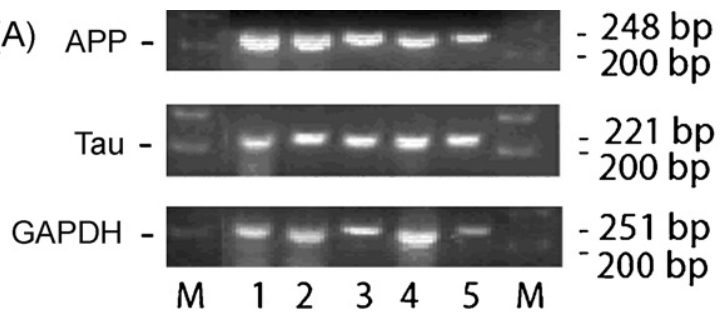

(B)

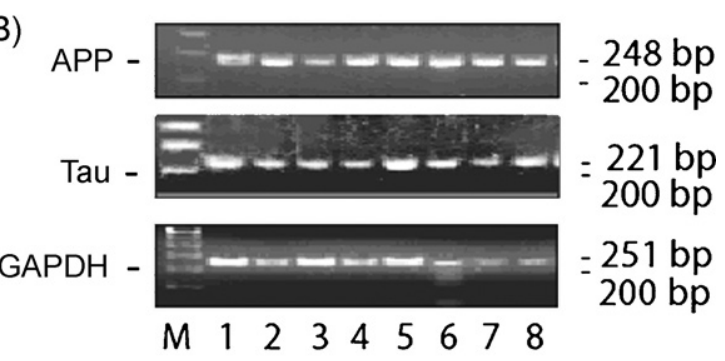

(C)

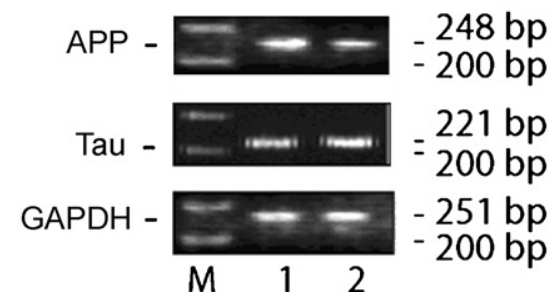

Fig. 1. Expression of APP and tau. mRNAs in human pancreas tissue, SHSY5Y and beta cell lines. (A) Ethidium bromide-stained agarose gel of RT-PCR products from human pancreas of 5 individuals, 3 with type 2 diabetes (lanes 1-3) and 2 controls (lanes 4 and 5). Molecular weight markers are shown on the right and left side. (B) Expression of APP and tau mRNAs in pancreas tissue of three additional diabetic (lanes $1,3,5$ ) and one control (lane 7) patients compared to the frontal cortex of the same patients (lanes $2,4,6,8$, respectively). (C) The expression of APP and tau mRNAs in cultured INS-1 beta cells was compared to those of neuroblastoma SH-SY5Y cells. Ethidium bromide-stained agarose gel of RT-PCR products from beta cells (lane 1) compared to SH-SY5Y cells (lane 2). Molecular weight markers are shown on the left side. Glyceraldehyde 3-phosphate dehydrogenase (GAPDH) was used to verify loading conditions.

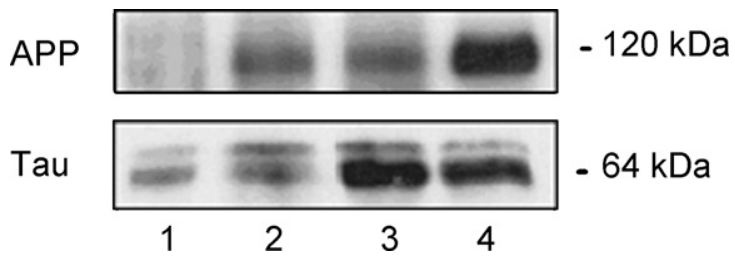

Fig. 2. Detection of APP and tau in human pancreas tissue by Western blot. Immunoblotting using a monoclonal anti-APP antibody (clone C2212) which recognizes a common $\mathrm{N}$ terminal epitope of the three major APP isoforms detects immunoreactive APP bands around $120 \mathrm{kDa}$ in three pancreas samples (lanes 1-2 correspond to controls and lane 3 to type 2 diabetes) when compared to N2a human neuroblastoma cells which are known to contain APP and tau and which were used as positive controls (lane 4). Two tau reactive bands of ca. 64 and $69 \mathrm{kDa}$ were detected with anti-tau, clone tau 2 antibody in the same pancreas samples similar to those of N2a neuroblastoma cells.

in the pancreas and frontal cortex were identical (Fig. 1B). The bands were also similar to those observed in INS-1 beta cells and SH-SY5Y cells (Fig. 1B). The GAPDH mRNA was used to verify loading conditions.

\subsection{Immunoblotting}

Fig. 2 illustrates immunoreactive bands of APP around $120 \mathrm{kDa}$ (lanes 1-3) in pancreatic extracts identical to those in the N2a cell line transiently transfected with APP and therefore over-expressing APP. A tau reactive doublet was also detected in the pancreas of the same patients (panel tau, lanes 1-3) similar to that of the N2a cell line which is known to express tau protein.

\subsection{Histochemistry and immunohistochemistry}

In the pancreas of patients with type 2 diabetes, on $\mathrm{H} \& \mathrm{E}$ stained sections the presence of amyloid deposits in Langerhans islets were often difficult to recognize (Fig. 3A outlined with arrows). However, in more affected areas of the pancreatic islets at higher magnification, the cytoplasm of some cells showed a homogenous eosinophilic appearance, sometimes with fine fibrillary changes occasionally in triangular shaped cells (Fig. 3B). Atherosclerotic changes of small and medium sized arteries of the pancreas were frequently observed. In a few cases, rare discrete lymphocytic infiltrates could be seen, particularly around the more affected areas of the pancreas, but in the majority of cases lymphocytic infiltrates were not visible on H\&E stained sections. Thioflavin S (Fig. 3C) and amylin immunoreactive (Fig. 3D) islet amyloid deposits were found in the pancreas in the 10 clinically and pathologically confirmed type 2 diabetic cases. Thioflavin $\mathrm{S}$ and congo Red positive and amylin immunoreactive islet amyloid deposits were not observed in the pancreas of the control cases without a clinical record of type 2 diabetes, except for two cases. These cases may represent a preclinical stage of the disease since in the clinically confirmed diabetic patients the islet amyloid deposits were more extensive and occupied larger areas of the islets. 


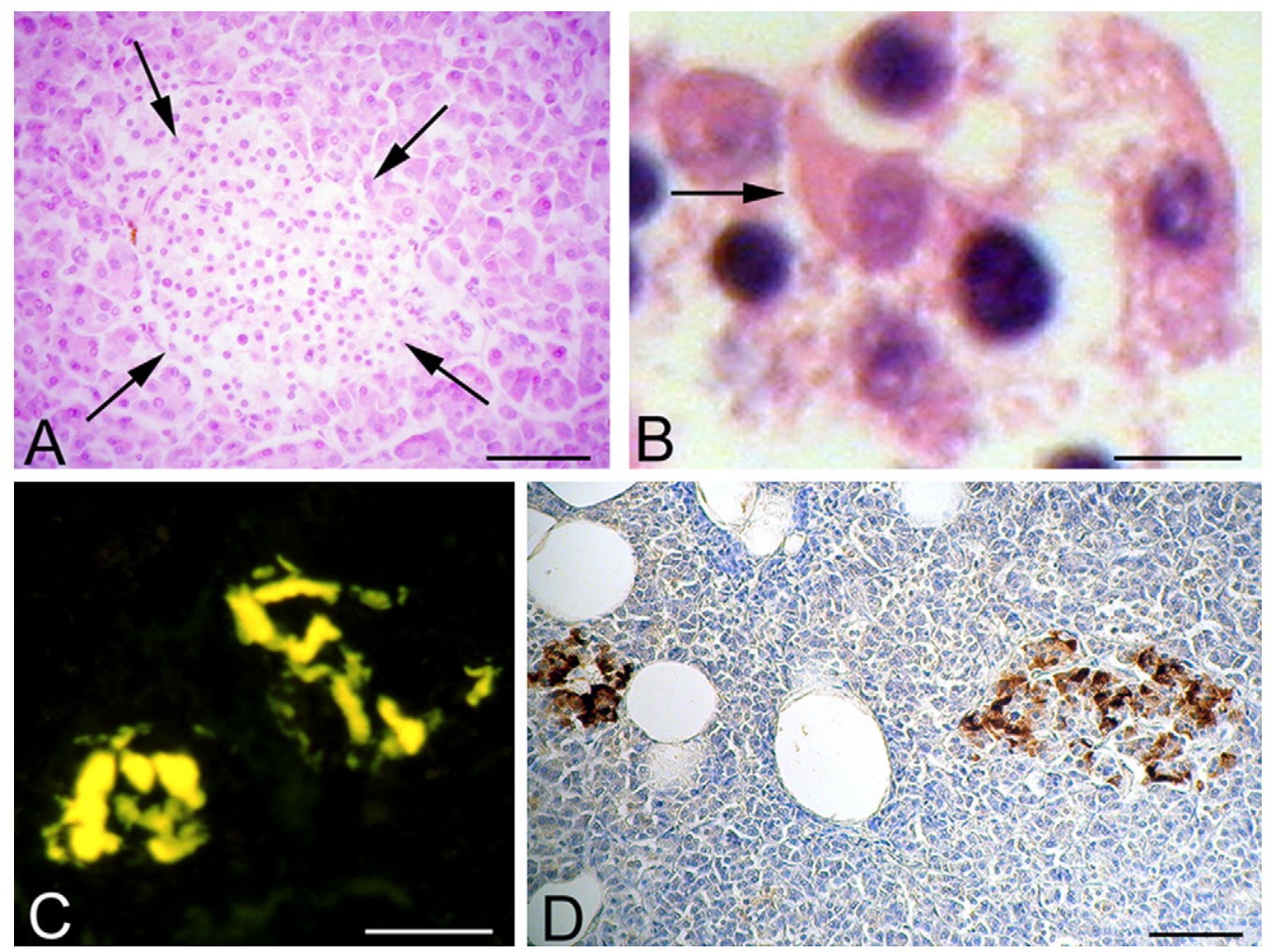

Fig. 3. Islet amyloid deposit in type 2 diabetes. (A) Section of the pancreas from a patient with type 2 diabetes stained with H\&E. Arrows point to a Langerhans islet, the site of amyloid deposition in type 2 diabetes, which is surrounded by acinar cells. At high magnification (B) a cell with "flame"-like triangular shape (arrow) and homogeneous eosinophilic cytoplasm is visible. (C) Islet amyloid deposits exhibiting positive fluorescence, localized in Langerhans islets in a case with type 2 diabetes as stained with the fluorochrome Thioflavin S which detects amyloid. (D) Amylin immunoreactive amyloid deposits localized to degenerating Langerhans islets in the pancreas of a patient with type 2 diabetes. Rabbit anti-amylin antibody raised against islet amyloid peptide (rabbit anti-IAPP 1-37) was used for immunostaining. Bar: (A) $150 \mu \mathrm{m}$; (B) $7 \mu \mathrm{m}$; (C) $150 \mu \mathrm{m}$; (D) $200 \mu \mathrm{m}$.

When pancreas sections were immunostained with the eight different anti-A $\beta$ antibodies, an almost identical immunoreaction was observed. The best results for $A \beta$ immunostaining were obtained on paraformadehyde fixed frozen sections. Immunostaining floating sections has given better results compared to sections mounted on slides. In all diabetic patients, islet amyloid deposits showed positive $A \beta$ immunostaining. This positive $A \beta$ immunoreactivity is illustrated for the $A \beta-42, A \beta-40$ and $4 \mathrm{G} 8$ antibodies in Fig. $4 \mathrm{~A}-\mathrm{C}$, respectively. A positive $\mathrm{A} \beta$ immunoreaction was also observed in the pancreas of the two clinically silent cases with less severe islet amyloid deposits where type 2 diabetes was not clinically confirmed. Similarly to amylin, $\mathrm{A} \beta$ immunoreactivity was also observed in larger, homogeneous extracellular islet amyloid deposits, particularly in more severely affected areas, but $\mathrm{A} \beta$ was also present intracellularly in a subset of cells of the Langerhans islets (Fig. 4D and $\mathrm{E})$. In some cases, scattered foci of $\mathrm{A} \beta$ deposits were observed in pancreatic acinar cells and in the walls of pancreatic blood vessels showing Thioflavin S positive amyloid deposits. When serial sections of pancreas from diabetic patients were immunostained for $A \beta$ and amylin, $A \beta$ and amylin were co-localized in islet amyloid deposits. Similar results were obtained when the same pancreas sections were double-stained using immunofluorescent secondary antibodies to $\mathrm{A} \beta$ and amylin (Fig. 4G-I).

With five different anti-tau-antibodies, including the two antibodies which recognize only phosphorylated tau, a positive immunoreaction in the degenerating pancreatic islets was present in all pancreases of patients with type 2 diabetes. This is illustrated for the phosphorylationindependent antibody A0024 (Fig. 5A and B) and for the phosphorylation-dependent antibody AT8 (Fig. 5C). Positive ubiquitin (Fig. 5D), Apo-E (Fig. 5E) and apo(a) (Fig. 5F) immunoreactions were also observed in association with islet amyloid deposits. IB1/JIP1 (Fig. 5G) and JNK-1 (Fig. 5H) positive immunoreactions in the cytoplasm of a subset of cells in the Langerhans islet, similar to that of phosphorylated tau, were also observed in all cases with type 2 diabetes.

On immunostained sections doubly stained with Thioflavin $\mathrm{S}$ the immunoreaction to $\mathrm{A} \beta$, (p)tau, ubiquitin, Apo-E, Apo-a, IB1 and JNK-1 were localized in the affected Langerhans islets in areas with islet amyloid deposits (not shown).

Control sections where the primary antibody was replaced with normal serum (Fig. 5I) were always negative. Except the two control cases where some islet amyloid deposits were observed, pancreas sections of the control cases were all negative (not shown). 


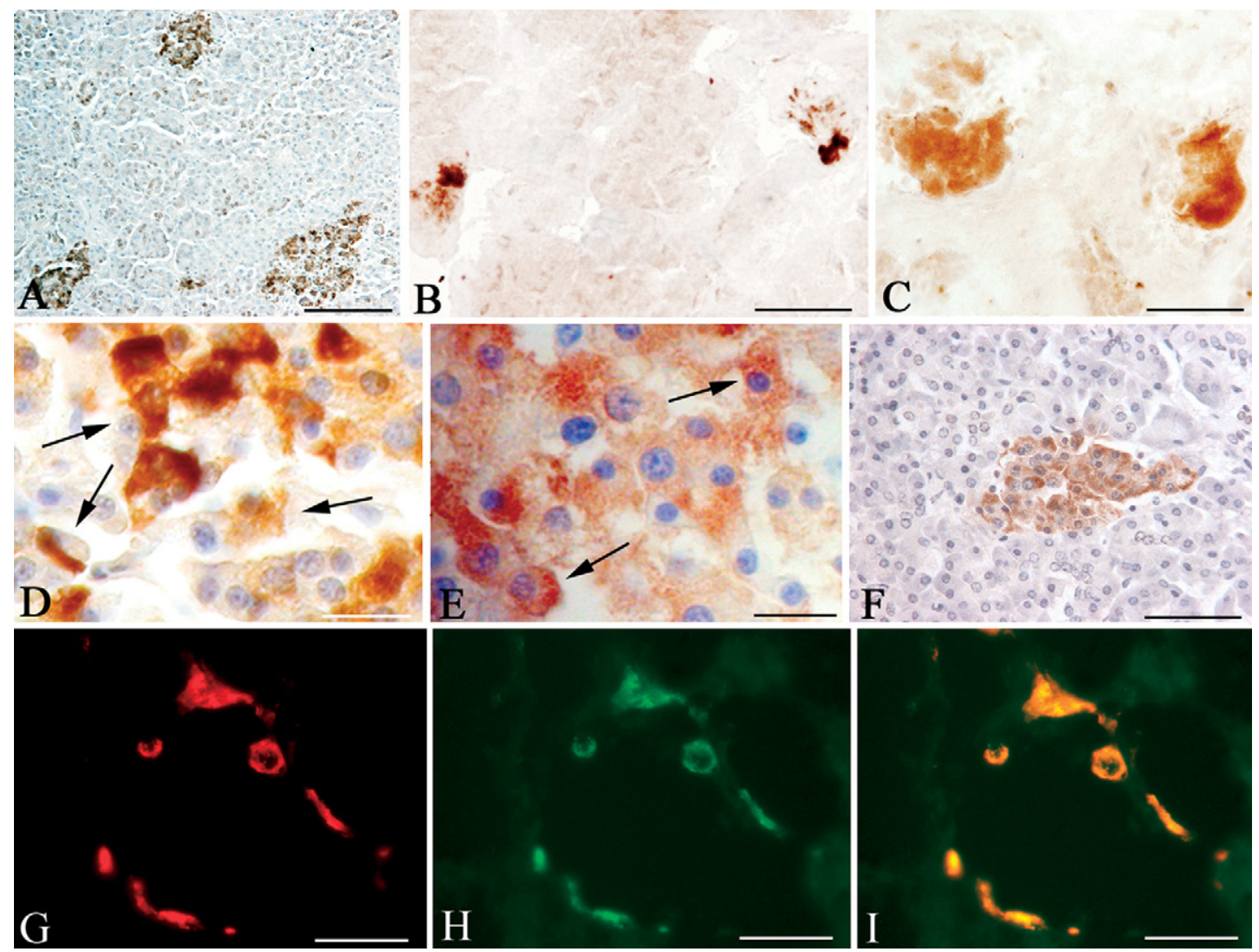

Fig. 4. $\mathrm{A} \beta$ in islet amyloid deposits in type 2 diabetes. (A) Islet amyloid deposits showing positive $A \beta$ immunoreaction with anti-A $\beta$ antibodies $21 \mathrm{~F} 12$ (A), 2F9AF (B) and 4G8 (C) which recognize different epitopes of the molecule (see Table 1). (D and E) Sections of the pancreas from a diabetic patient immunostained with rabbit anti-amylin antibody (D, IAPP 1-37, Dr. A. Clark) and with the 4G8 monoclonal anti-A $\beta$ antibody (E) showing their intracellular localization (arrows). (F) Small group of affected acinar cells showing $A \beta$ immunoreaction demonstrated with the anti-A $\beta$ monoclonal antibody 21F12. (G-I) Pancreas section of a patient with type 2 diabetes doubly immunostained with an anti-amylin monoclonal antibody (GTX 74673, GeneTex, Inc.) labeled with TRITC-tagged secondary anti-mouse antibody (which gives a red fluorescence for amylin) (G) and with a polyclonal antibody to the C terminus of $\mathrm{A} \beta \mathrm{40}$ ) (Dr. H. Mori) which was labeled with a FITC-tagged anti-rabbit secondary antibody shows a green fluorescence. The orange color of the merged image shows the co-localization of amylin and $\mathrm{A} \beta$ in islet amyloid deposits. Bars: (A and C) $250 \mu \mathrm{m},(\mathrm{B}) 70 \mu \mathrm{m},(\mathrm{D}$ and $\mathrm{E}) 50 \mu \mathrm{m},(\mathrm{F}) 200 \mu \mathrm{m}$, (G-I) $120 \mu \mathrm{m}$.

\subsection{Synchrotron infrared microspectroscopy}

Fig. 6 shows the in situ infrared absorption microspectra of islet amyloid deposits in type 2 diabetes, as analyzed by SIRMS which showed a protein (Amide I) absorbance maximum near $1630 \mathrm{~cm}^{-1}$ representative of $\beta$-sheet protein structure. In areas of the pancreas without amyloid deposits, the absorbance maximum was near $1655 \mathrm{~cm}^{-1}$ which corresponds to $\alpha$-helical protein structure typical of healthy tissue.

\subsection{Effect of LPS and insulin on APP}

Increased APP levels were detected in U87MG and TE671 cells, comparable to those in PC12 cells following exposure to $500 \mathrm{ng} / \mathrm{ml}$ of LPS. Human recombinant insulin $(100 \mathrm{ng} / \mathrm{ml})$ decreased APP levels in PC12, U87MG and TE671 cells following 6-48 h of exposure. The influence of LPS and insulin on PC12 and TE671 cells is illustrated in Figs. 7 and 8.

\section{Discussion}

Type 2 diabetes accounts for $90-95 \%$ of all diabetic cases and has become a major health concern (Biessels et al., 2006). The percentage of type 2 diabetes among AD patients is significantly higher than among age-matched non-AD controls (Kuusisto et al., 1997; Ott et al., 1999). Conversely, patients with type 2 diabetes have twice the risk of controls to develop AD (Arvanitakis et al., 2004; Grodstein et al., 2001; Leibson et al., 1997; Ott et al., 1999; Peila et al., 2002; Xu et al., 2004).

Dysregulation of APP metabolism results in fibrillary A $\beta$ deposits in AD brain and dysregulation of tau metabolism results in fibrillary hyperphosphorylated tau deposits in neurons. The presence of APP and tau which have general regulatory functions in various cells of other organs than brain would suggest that increased APP and hyperphosphorylation of tau might be expected to be associated with various other pathological conditions as well. Indeed, $A \beta$ deposition and pathological fibrillary lesions showing similar immunohistochemical and ultrastructural properties to tangles and 


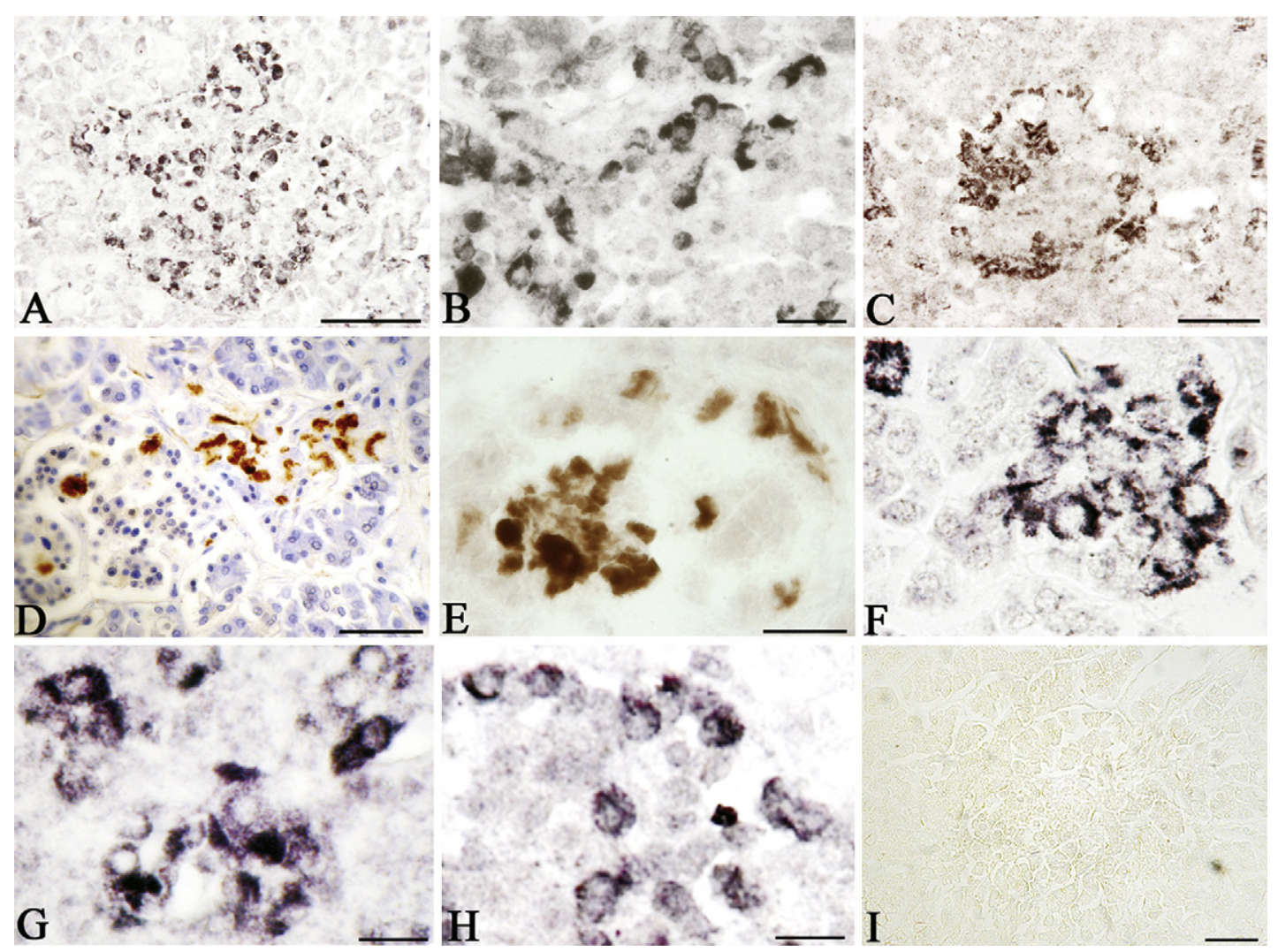

Fig. 5. Hyperphosphorylated tau in the pancreas in type 2 diabetes. (A-C) Pancreas sections of patient with type 2 diabetes showing a positive immunoreaction to tau A0024 (A and B) and AT8 (C). Positive immunoreaction in the affected Langerhans islet to Ubiquitin (D), apo-E (E), Apo(a) (F), IB1/JIP-1 (G) and JNK1 (H). (I) Control section where the primary antibody was replaced by normal serum. Bars: (A and C) $250 \mu \mathrm{m}$, (B) $70 \mu \mathrm{m}$, (D) $200 \mu \mathrm{m}$, (E-I) $100 \mu \mathrm{m}$.

neuropil threads have been reported in several other organs and tissues than the brain (Joachim et al., 1989; Askanas et al., 1994; Miklossy et al., 1998; Miklossy et al., 1999; Askanas and Engel, 2002; Dentchev et al., 2003; Goldstein et al., 2003). We suspected this might be the case for the pancreas in type 2 diabetes and found evidence supporting this hypothesis.

The expression of APP and tau mRNAs by RT-PCR in human pancreas (both in type 2 diabetes and controls) and in INS-1 beta cells, as well as the detection of APP and tau immunoreactive bands by Western blot indicates that similarly to the brain APP and tau are present in the pancreas tissue and in beta cells. A detailed immunohistochemical investigation to detect aggregated $A \beta$ in pancreas tissue in type 2 diabetes, using a panel of anti-A $\beta$ antibodies recognizing different epitopes of $A \beta$, showed that islet amyloid deposits are also immunoreactive to $A \beta$. On serial sections or on sections doubly immunostained for $A \beta$ and amylin, they were co-localized in these deposits. Antibodies to hyperphosphorylated tau also labeled a subset of cells in the affected Langerhans islets in patients with type 2 diabetes. These results indicate that $A \beta$ formation and tau phosphorylation are also features of type 2 diabetes.

In the adult brain, alternative splicing of tau mRNA leads to six tau isoforms which contain either three (3R) or four
(4R) microtubule-binding repeat domains (Goedert et al., 1989). The brain of healthy individuals contains similar levels of $3 \mathrm{R}$ and $4 \mathrm{R}$ tau. $4 \mathrm{R}$ tau binds and stabilizes microtubule more efficiently (Panda et al., 2003). Changes in the $3 \mathrm{R} / 4 \mathrm{R}$ ratio and hyperphosphorylation diminish the ability of tau to bind microtubules. Unbounded hyperphosphorylated tau aggregates and forms fibrillary aggregates or tangles in neurons, astrocytes and/or oligodendroglial cells. The tau inclusions of these various neurodegenerative disorders or tauopathies, which include $\mathrm{AD}$, differ by their proportion of 3R/4R tau isoforms, their phosphorylation sites and ultrastructure (paired helical, straight or random coiled filaments). The major doublet $64 / 69 \mathrm{kDa}$ observed in the pancreas of healthy and diabetic patients may be, indicative of 4R tauopathy which is characteristic of progressive supranuclear palsy (PSP) and cortico-basal degeneration (CBD) where glial tau inclusions predominate. It is distinct from the major tau triplet at 60,64 and $69 \mathrm{kDa}$ of AD. Further studies will be necessary to define the exact combination of tau isoforms, the specific phosphorylation pattern and the types of pathological filaments of tau aggregates accumulating in islet cells in type 2 diabetes.

Tau protein mRNA was found in equal amount in the pancreas of patients with type 2 diabetes compared to controls, whereas tau protein levels were different, which may 

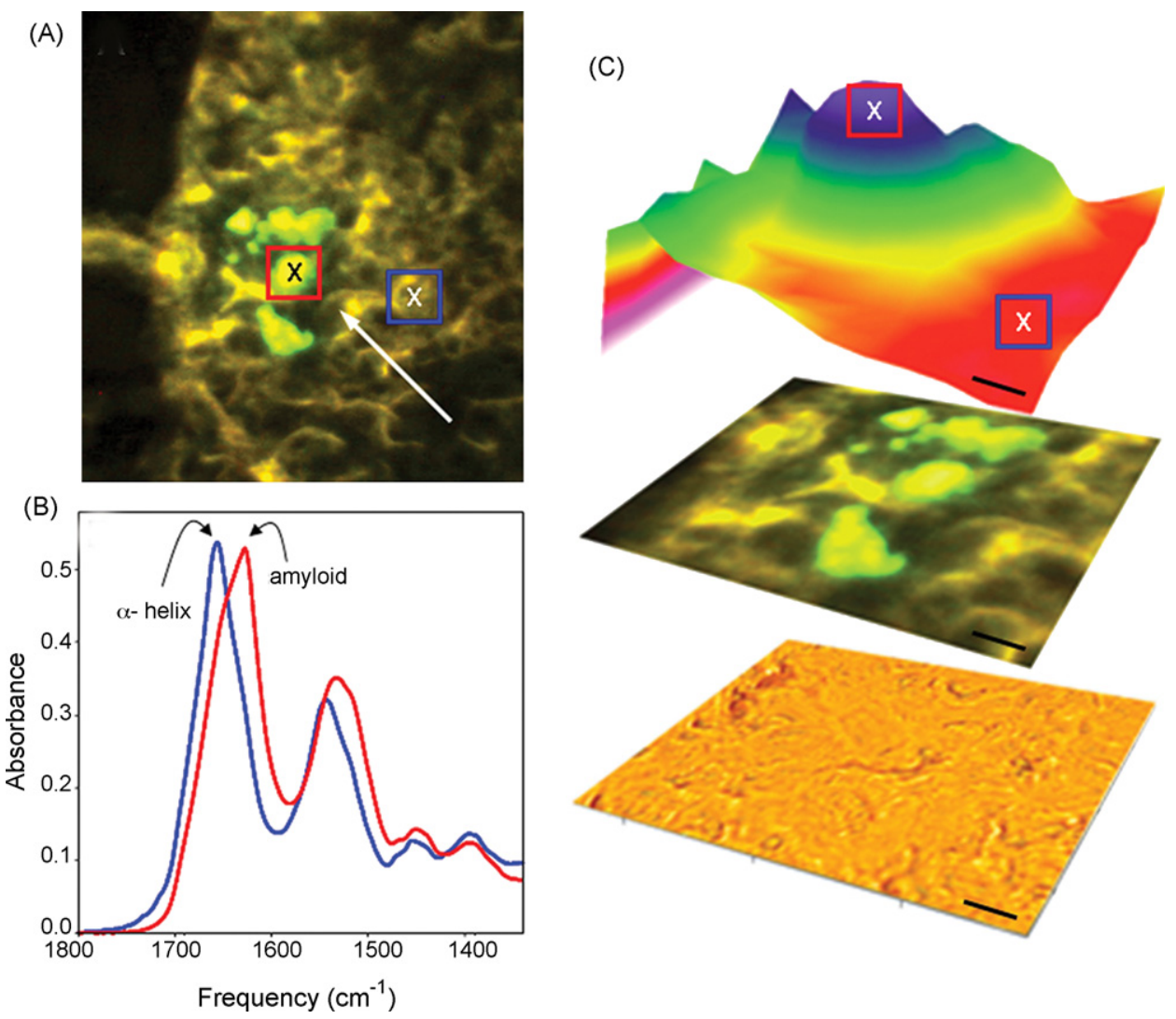

Fig. 6. Synchrotron infrared microspectroscopy (SIRMS) analysis of islet amyloid deposits. (A) Epifluorescence image showing Thioflavin S positive amyloid deposits (arrow). (B and C) Infrared absorption image of protein structure $\left(1630 / 1655 \mathrm{~cm}^{-1}\right.$ ) showed an absorbance maximum near $1630 \mathrm{~cm}^{-1}$ representative of $\beta$-sheet protein structure. In areas of the pancreas without Thioflavin S stained amyloid, the absorbance maximum was near $1655 \mathrm{~cm}^{-1}$ corresponding to $\alpha$-helical protein structure. Scale bar: $10 \mu \mathrm{m}$.

suggest abnormalities downstream to DNA transcription. Further studies of representative number of cases will be necessary to address this question.

The in situ secondary structure of islet amyloid deposit was not analyzed before. Using SIRMS the protein secondary structure of islet amyloid deposits was determined in situ in the areas of Thioflavin $\mathrm{S}$ positive islet deposits, by amide I infrared absorption band $\left(1600-1700 \mathrm{~cm}^{-1}\right)$ analysis . The frequency of Amide I band is sensitive to protein secondary structure, where $\beta$-sheet conformation absorbs near $1630 \mathrm{~cm}^{-1}$. The in situ infrared absorption microspectrum in the pancreas of patients with type 2 diabetes showed a $1630 \mathrm{~cm}^{-1}$ peak corresponding to $\beta$-sheet protein structure. It was identical to the in situ infrared microspectra of beta amyloid deposits in senile plaques (Choo et al., 1996; Miklossy et al., 2006b). SIMRS cannot distinguish between the beta sheet structure of amylin and $A \beta$. However, it clearly shows that in the affected areas of the Langerhans islet, where amylin and $\mathrm{A} \beta$ were immune co-localized, the homogenous protein deposits indeed correspond to amyloid substance with the typical beta sheet structure.

It is well established that Apo-E plays an important role in the pathogenesis of late onset $\mathrm{AD}$, with the $\mathrm{E} 4$ allele being a significant risk factor. There have been reports of Apo-E asso- ciation with amyloid deposits independently of the primary amyloid protein (Wisniewski and Frangione, 1992; Charge et al., 1996). Apo(a), which shares a series of common features with Apo-E, is also implicated in the development of late onset AD (Mooser et al., 2000). Our results showing a positive immunoreaction in association with pancreatic lesions not only to ubiquitin, but to Apo-E and Apo(a) as well, further point to the existence of common features in the pathogenesis of $\mathrm{AD}$ and type 2 diabetes.

Mitogen-activated protein kinases (MAPKs) are key enzymes involved in diverse cellular processes in response to extracellular stimuli. They regulate cell survival, cell death, proliferation and/or differentiation. Activation of the ERK forms of MAPK causes survival responses, whereas activation of the p38 and c-Jun NH2-terminal kinase (JNK) promotes cell death. JNK, for its action, requires the presence of a scaffold protein islet-brain-1 (IB1) or C-Jun $\mathrm{N}$-terminal kinase interacting protein-1 (IB1/JIP-1). The gene MAPK8IP1, encoding IB1/JIP1 is a candidate for type 2 diabetes (Waeber et al., 2000) and a promoter variant of IB1/JIP1 is associated with AD (Helbecque et al., 2003). The cytoplasmic tail of APP interacts with IB1/JIP1 and JNK is required for APP phosphorylation. IB-1 and JNK-1 are colocalized with phosphorylated tau in neurofibrillary tangles 


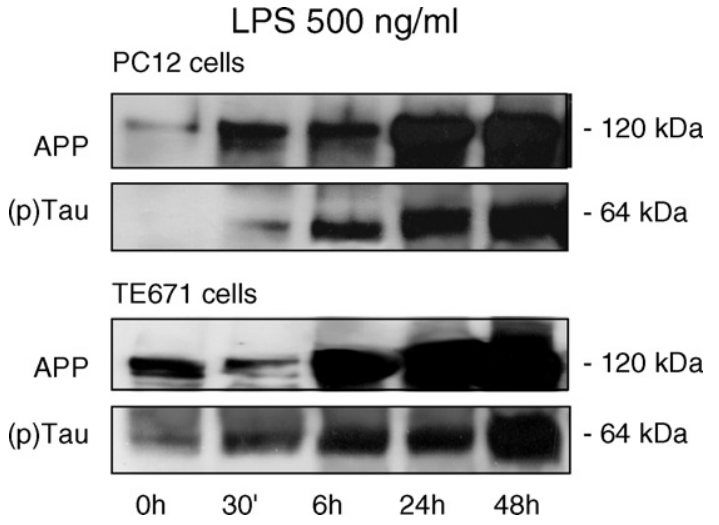

Fig. 7. LPS increases APP levels in PC12 and TE671 cells. Western blot analysis of PC12 and TE671 cells using anti-APP 22C11 antibody detected increased APP levels following 6 and 24 and $48 \mathrm{~h}$ of LPS exposure. The increased APP levels were comparable in PC12 and TE671 cells.

in $\mathrm{AD}$ (Helbecque et al., 2003). The present results show that in the pancreas of patients with type 2 diabetes, degenerating cells of the Langerhans islets are strongly immunoreactive to IB1/JIP1 and JNK-1 as well.

Inflammatory processes play an important role in $\mathrm{AD}$ and experimentally increased APP levels and consequent A $\beta$ 142 accumulation were observed in neurons and in the CNS in experimental animals following exposure to LPS. As APP is a phylogenetically stable protein we expected that LPS may influence APP levels in non-neuronal cells as well. Indeed the present findings show that LPS induces increased APP levels not only in PC12 cells but in non-neuronal cells as well. The protective effect of insulin on neurons is well known. Here we show that insulin decreases APP not only in PC12 cells but also in cells without neuronal properties. These results further suggest that a host reaction with elevated APP may occur (e.g. induced by inflammatory stimuli) in various other organs than the brain. They also suggest that the decreased protective effect of insulin in type 2 diabetes may also lead to APP dysregulation and may be one of the mechanisms involved in amyloid formation in the CNS and in various other organs.

Despite the fact that convincing clinical, epidemiological (reviewed by Grossman, 2003; Arvanitakis et al., 2006;

\section{Insulin 100ng/ml}

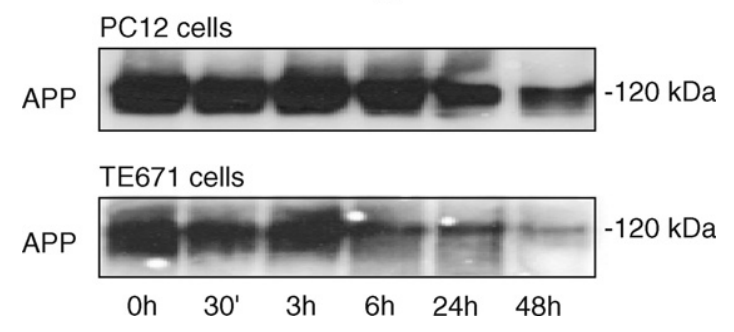

Fig. 8. Western blot analysis of APP levels in PC12 and TE671 cells following exposure to insulin. Decreased APP levels were detected following 6-48 $\mathrm{h}$ of exposures to human recombinant insulin $100 \mathrm{ng} / \mathrm{ml}$ exposures in PC12 and in non-neuronal TE671 cells.
Alafuzoff et al., 2008) and genetic studies (Bertram et al., 2000; Duggirala et al., 2001; Myers and Goata, 2001; Tanzi and Bertram, 2001; Qui and Folstein, 2006) have provided substantial evidence in favor of a link between AD and type 2 diabetes, studies analyzing AD-related pathology in diabetic cases compared with non-diabetic patients failed to show such association (Arvanitakis et al., 2006; Alafuzoff et al., 2008). Recently, evidence for the pathological interaction between diabetes and presymptomatic Alzheimer's disease was reported (Burdo et al., 2008).

Both, $\mathrm{AD}$ and type 2 diabetes are slowly progressive disorders with a high prevalence in the elderly population over 65 years. In both, clinically silent amyloid deposits and pathological tau aggregates may precede by years or even decades the clinical manifestation of dementia and type 2 diabetes. These clinically silent mild and moderate amyloid deposits and tau pathology may correspond to early, preclinical stages of these diseases. Further prospective studies are necessary to analyze a putative association between amyloid and tau deposits in pancreatic islets and cortical AD pathology. The comparison of the frequency of diabetic cases in definite $\mathrm{AD}$ and age-matched controls without AD-type cortical pathology may give further information. The analysis of the number of diabetic patients in preclinical stages of $\mathrm{AD}$ (Braak stages I-IV) compared to controls without AD pathology may also be useful.

Future prospective studies using quantitative analysis of standard pancreas samples taken from the head, body and tail of the pancreas should be done. It may enable comparison of the severity of islet $A \beta$ and tau pathology between diabetic cases, between diabetic and control cases. Comparison of the results with cortical $A \beta$ and tau pathology in brains of the same patients and correlating them with the clinical severity of type 2 diabetes and cognitive decline may give important information. Further immunohistochemical analyses by double labeling pancreas sections using combination of antibodies to various pathological proteins with amylin and with antibodies detecting different islet cell types $(\alpha, \beta, \delta, \varepsilon, \mathrm{PP}$ cells) would give further information on the exact cellular location and co-localization of pathological proteins and on the types of islet cells involved.

In conclusion, $A \beta$ deposits and/or hyperphosphorylation of tau are the most important biological markers of $\mathrm{AD}$ and various other neurodegenerative disorders. APP is a phylogenetically highly conserved protein which is also synthesized by various cells outside the CNS. The present results showed that $\mathrm{A} \beta$ deposition, hyperphosphorylation of tau, as well as ubiquitin and Apo-E immunoreactivities are characteristic features of type 2 diabetes. Apo(a), IB1/JIP-1 and JNK-1 are also associated with both $\mathrm{AD}$ and type 2 diabetes. They indicate that some common features are implicated in the pathogenesis of $\mathrm{AD}$ and type 2 diabetes and that $\mathrm{A} \beta$ deposition and hyperphosphorylation of tau may be part of a widespread systemic host reaction. The inflammatory stimulator and amyloidogenic LPS increases APP levels not only in neuronal but in non-neuronal cells as well. Decreased insulin 
in type 2 diabetes may also participate in APP dysregulation and $A \beta$ accumulation.

\section{Disclosure}

The authors have no actual or potential interest to disclose.

\section{Acknowledgements}

We are particularly grateful to all the pathologist colleagues at the University Institute of Pathology, Lausanne, Switzerland, who helped to collect part of the tissue samples from various other organs than the brain, including the pancreas. Their dedicated help through more than two decades resulted in several studies. Without their efforts, this work would not have been completed. We are particularly grateful to Pushpa Darekar for her devoted help and contribution to the present work and to Dr Santica Marcovina (University of Washington, Seattle WA) for the generous gift of the anti-apo(a) antibodies. This research was supported by grants from the Société Académique Vaudoise, Fondation Fern Moffat, as well as from the Jack Brown and Family Foundation and The Pacific Alzheimer Research Foundation from British Columbia, Canada.

\section{References}

Alafuzoff, I., Aho, L., Helisalmi, S., Mannermaa, A., Soininen, H., 2008. $\beta$-Amyloid deposition in brains of subjects with diabetes. Neuropathol. Appl. Neurobiol, doi:10.1111/j.1365-2990.2008.00948.x.

Arvanitakis, Z., Wilson, R.S., Bienias, J.L., Evans, D.A., Bennett, D.A., 2004. Diabetes mellitus and risk of Alzheimer disease and decline in cognitive function. Arch. Neurol. 61, 661-666.

Arvanitakis, Z., Schneider, J.A., Wilson, R.S., Li, Y., Arnold, S.E., Wang, Z., Bennett, D.A., 2006. Diabetes is related to cerebral infarction but not to AD pathology in older persons. Neurology 67, 1960-1965.

Asfari, M., Janjic, D., Meda, P., Li, G., Halban, P.A., Wollheim, C.B., 1992. Establishment of 2-mercaptoethanol-dependent differentiated insulinsecreting cells. Endocrinology 130, 167-178.

Askanas, V., Engel, W.K., Bilak, M., Alvarez, R.B., Selkoe, D.J., 1994. Twisted tubulofilaments of inclusion body myositis muscle resemble paired helical filaments of Alzheimer brain and contain hyperphosphorylated tau. Am. J. Pathol. 144, 177-187.

Askanas, V., Engel, W.K., 2002. Newest pathogenetic considerations in inclusion-body myositis: possible role of amyloid-beta, cholesterol, relation to aging and to Alzheimer's disease. Curr. Rheumatol. Rep. 4, 427-433.

Bertram, L., Blacker, D., Mullin, K., Keeney, D., Jones, J., Basu, S., Yhu, S., McInnis, M.G., Go, R.C., Vekrellis, K., Selkoe, D.J., Saunders, A.J., Tanzi, R.E., 2000. Evidence for genetic linkage of Alzheimer's disease to chromosome 10q. Science 290, 2302-2303.

Biessels, G.J., Staekenborg, S., Brunner, E., Brayne, C., Scheltens, P., 2006. Risk of dementia in diabetes mellitus: a systematic review. Lancet Neurol. 5, 64-74.

Burdo, J.R., Chen, Q., Calcutt, N.A., Schubert, D., 2008. The pathological interaction between diabetes and presymptomatic Alzheimer's disease. Neurobiol. Aging (Epub ahead of print), doi:10.1016/j.neurobiolaging.2008.02.010.
Charge, S.B., Esiri, M.M., Bethune, C.A., Hansen, B.C., Clark, A., 1996. Apolipoprotein $\mathrm{E}$ is associated with islet amyloid and other amyloidoses: implications for Alzheimer's disease. J. Pathol. 179, 443-447.

Choo, L.P., Wetzel, D.L., Halliday, W.C., Jackson, M., LeVine, S.M., Mantsch, H.H., 1996. In situ characterization of beta-amyloid in Alzheimer's diseased tissue by synchrotron Fourier transform infrared microspectroscopy. Biophys. J. 71, 1672-1679.

Cooper, G.J.S., Willis, A.C., Clark, A., Turner, R.C., Sim, R.B., Reid, K.B.M., 1987a. Purification and characterization of a peptide from amyloid-rich pancreases of type 2 diabetic patients. Proc. Natl. Acad. Sci. U.S.A. 84, 8628-8632.

Cooper, G.J., Willis, A.C., Reid, K.B., Clark, A., Baker, C.A., Turner, R.C., Lewis, C.E., Morris, J.F., Howland, K., Rothbard, J.B., 1987b. Diabetesassociated peptide. Lancet 2 (8565), 966.

Cooper, G.J., Leighton, B., Dimitriadis, G.D., Parry-Billings, M., Kowalchuk, J.M., Howland, K., Rothbard, J.B., Willis, A.C., Reid, K.B., 1988. Amylin found in amyloid deposits in human type 2 diabetes mellitus may be a hormone that regulates glycogen metabolism in skeletal muscle. Proc. Natl. Acad. Sci. U.S.A. 85, 7763-7766.

Dentchev, T., Milam, A.H., Lee, V.M., Trojanowski, J.Q., Dunaief, J.L., 2003. Amyloid-beta is found in drusen from some age-related macular degeneration retinas, but not in drusen from normal retinas. Mol. Vis. 9, 184-190.

Goldstein, L.E., Muffat, J.A., Cherny, R.A., Moir, R.D., Ericsson, M.H., Huang, X., Mavros, C., Coccia, J.A., Faget, K.Y., Fitch, K.A., Masters, C.L., Tanzi, R.E., Chylack Jr., L.T., Bush, A.I., 2003. Cytosolic betaamyloid deposition and supranuclear cataracts in lenses from people with Alzheimer's disease. Lancet 361, 1258-1265.

Grodstein, F., Chen, J., Wilson, R.S., Manson, J.E., 2001. Type 2 diabetes and cognitive function in community-dwelling elderly women. Diabetes Care 24, 1060-1065.

Duggirala, R., Blangero, J., Almasy, L., Arya, R., Dyer, T.D., Williams, K.L., Leach, R.J., O'Connell, P., Stern, M.P., 2001. A major locus for fasting insulin concentrations and insulin resistance on chromosome $6 \mathrm{q}$ with strong pleiotropic effects on obesity-related phenotypes in nondiabetic Mexican Americans. Am. J. Hum. Genet. 68, 1149-1169.

Goedert, M., Spillantini, M.G., Jakes, R., Rutherford, D., Crowther, R.A., 1989. Multiple isoforms of human microtubule-associated protein tau: sequences and localization in neurofibrillary tangles of Alzheimer's disease. Neuron 3, 519-526.

Grossman, H., 2003. Does diabetes protect or provoke Alzheimer's disease? Insights into the pathobiology and future treatment of Alzheimer's disease. C.N.S. Spectr. 8, 815-823.

Helbecque, N., Abderrahamani, A., Meylan, L., Riederer, B., Mooser, V., Miklossy, J., Delplanque, J., Boutin, P., Nicod, P., Haefliger, J.A., Cottel, D., Amouyel, P., Froguel, P., Waeber, G., 2003. Islet-brain1/C-Jun $\mathrm{N}$-terminal kinase interacting protein-1 (IB1/JIP-1) promoter variant is associated with Alzheimer's disease. Mol. Psychiatry 4, 413-422.

Hull, R.L., Westermark, G.T., Westermark, P., Kahn, S.E., 2004. Islet amyloid: a critical entity in the pathogenesis of type 2 diabetes. J. Clin. Endocrinol. Metab. 89, 3629-3643.

Janson, J., Laedtke, T., Parisi, J.E., O'Brien, P., Petersen, R.C., Butler, P.C., 2004. Increased risk of type 2 diabetes in Alzheimer disease. Diabetes $53,474-481$

Joachim, C.L., Mori, H., Selkoe, D.J., 1989. Amyloid beta-protein deposition in tissues other than brain in Alzheimer's disease. Nature 341, 226-230.

Johnson-Wood, K., Lee, M., Motter, R., Hu, K., Gordon, G., Barbour, R., Khan, K., Gordon, M., Tan, H., Games, D., Lieberburg, I., Schenk, D., Seubert, P., McConlogue, L., 1997. Amyloid precursor protein processing and A beta42 deposition in a transgenic mouse model of Alzheimer disease. Proc. Natl. Acad. Sci. U. S. A. 94, 1550-1555.

Kuusisto, J., Koivisto, K., Mykkanen, L., Helkala, E.L., Vanhanen, M., Hanninen, T., Kervinen, K., Kesaniemi, Y.A., Riekkinen, P.J., Laakso, M., 1997. Association between features of the insulin resistance syndrome and Alzheimer's disease independently of apolipoprotein E4 phenotype: cross sectional population based study. BMJ 315, 1045-1049. 
Leibson, C.L., Rocca, W.A., Hanson, V.A., Cha, R., Kokmen, E., O’Brien, P.C., Palumbo, P.J., 1997. The risk of dementia among persons with diabetes mellitus: a population-based cohort study. Ann. NY Acad. Sci. 826, 422-427.

Lopes, D.H., Colin, C., Degaki, T.L., de Sousa, A.C., Vieira, M.N., Sebollela, A., Martinez, A.M., Bloch Jr., C., Ferreira, S.T., Sogayar, M.C., 2004. Amyloidogenicity and cytotoxicity of recombinant mature human islet amyloid polypeptide (rhIAPP). J. Biol. Chem. 279, 4280342810.

Marcovina, S.M., Albers, J.J., Gabel, B., Koschinsky, M.L., Gaur, V.P., 1995. Effect of the number of apolipoprotein(a) kringle 4 domains on immunochemical measurements of lipoprotein(a). Clin. Chem. 41, 246-255.

Martin, D., Tawadros, T., Meylan, L., Abderrahmani, A., Condorelli, D.F., Waeber, G., Haefliger, J.A., 2003. Critical role of the transcriptional repressor neuron-restrictive silencer factor in the specific control of connexin36 in insulin-producing cell lines. J. Biol. Chem. 278, 53082-53089.

Miklossy, J., Lepori, D., Genton, C., Kraftsik, R., Pillevuit, O., Bosman, F.T., 1998. Curly fiber and tangle-like structures in the ependyma and the choroid plexus - a pathogenetic relationship with the cortical Alzheimertype changes? J. Neuropathol. Exp. Neurol. 57, 104-114.

Miklossy, J., Taddei, K., Martins, R., Escher, G., Kraftsik, R., Pillevuit, O., Lepori, D., Campiche, M., 1999. Alzheimer disease: curly fibers and tangles in organs other than brain. J. Neuropathol. Exp. Neurol. 58, 803-814.

Miklossy, J., Arai, T., Guo, J.P., Klegeris, A., Yu, S., McGeer, E.G., McGeer, P.L., 2006. LRRK2 expression in normal and pathologic human brain and in human cell lines. J. Neuropathol. Exp. Neurol. 65, 953-963.

Miklossy, J., Kis, A., Radenovic, A., Miller, L., Forro, L., Martins, R., Reiss, K., Darbinian, N., Darekar, P., Mihaly, L., Khalili, K., 2006b. Betaamyloid deposition and Alzheimer's type changes induced by Borrelia spirochetes. Neurobiol. Aging 27, 228-236.

Mooser, V., Helbecque, N., Miklossy, J., Marcovina, S.M., Nicod, P., Amouyel, P., 2000. Interactions between apolipoprotein E and apolipoprotein(a) in patients with late-onset Alzheimer disease. Ann. Intern. Med. 132, 533-537.

Myers, A.J., Goata, A.M., 2001. The genetics of late-onset Alzheimer's disease. Curr. Opin. Neurol. 14, 433-440.

O'Brien, J.A., Patrick, A.R., Caro, J., 2003. Estimates of direct medical costs for microvascular and macrovascular complications resulting from type 2 diabetes mellitus in the United States in 2000. Clin. Ther. 25, 1017-1038.
Ott, A., Stolk, R.P., van Harskamp, F., Pols, H.A., Hofman, A., Breteler, M.M., 1999. Diabetes mellitus and the risk of dementia: the Rotterdam study. Neurology 53, 1937-1942.

Panda, D., Samuel, J.C., Massie, M., Feinstein, S.C., Wilson, L., 2003. Differential regulation of microtubule dynamics by three- and four-repeat tau: implications for the onset of neurodegenerative disease. Proc. Nat. Acad. Sci. 100, 9548-9553.

Peila, R., Rodriguez, B.L., Launer, L.J., 2002. Type 2 diabetes, APOE gene, and the risk for dementia and related pathologies: the Honolulu-Asia aging study. Diabetes 51, 1256-1262.

Pellet, J.B., Haefliger, J.A., Staple, J.K., Widmann, C., Welker, E., Hirling, H., Bonny, C., Nicod, P., Catsicas, S., Waeber, G., Riederer, B.M., 2000. Spatial, temporal and subcellular localization of islet-brain 1 (IB1), a homologue of JIP-1, in mouse brain. Eur. J. Neurosci. 12, 621-632.

Qui, W.Q., Folstein, M.F., 2006. Insulin, insulin-degrading enzyme and amyloid $\beta$ peptide in Alzheimer's disease: review and hypothesis. Neurobiol. Aging 27, 190-198.

Ristow, M., 2004. Neurodegenerative disorders associated with diabetes mellitus. J. Mol. Med. 82, 510-529.

Sanke, T., Bell, G.I., Sample, C., Rubenstein, A.H., Steiner, D.F., 1988. An islet amyloid peptide is derived from an 89-amino acid precursor by proteolytic processing. J. Biol. Chem. 263, 17243-17246.

Tanzi, R.E., Bertram, L., 2001. New frontiers in Alzheimer's disease genetics. Neuron 32, 181-184.

Voisin, T., Lugardon, S., Balardy, L., Vellas, B., 2003. Vascular risk factors and Alzheimer's disease. Rev. Med. Intern. 24 (Suppl. 3), 288-291.

Waeber, G., Delplanque, J., Bonny, C., Mooser, V., Steinmann, M., Widmann, C., Maillard, A., Miklossy, J., Dina, C., Hani, E.H., Vionnet, N., Nicod, P., Boutin, P., Froguel, P., 2000. The gene MAPK8IP1, encoding islet-brain-1, is a candidate for type 2 diabetes. Nat. Genet. 3, 291-295.

Westermark, P., Wernstedt, C., O'Brien, T.D., Hayden, D.W., Johnson, K.H., 1987. Islet amyloid in type 2 human diabetes mellitus and adult diabetic cats contains a novel putative polypeptide hormone. Am. J. Pathol. 127, 414-417.

Wisniewski, T., Frangione, B., 1992. Apolipoprotein E: a pathological chaperone protein in patients with cerebral and systemic amyloid. Neurosci. Lett. 135, 235-238.

Xu, W.L., Qiu, C.X., Wahlin, A., Winblad, B., Fratiglioni, L., 2004. Diabetes mellitus and risk of dementia in the Kungsholmen project: a 6-year follow-up study. Neurology 63, 1181-1186.

Yasojima, K., McGeer, E.G., McGeer, P.L., 2001. High stability of mRNAs postmortem and protocols for their assessment by RT-PCR. Brain Res. Brain Res. Protoc. 8, 212-218. 